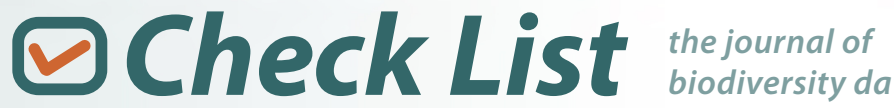

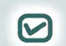

\section{An historical record for the distribution of Euphractus sexcinctus (Xenarthra, Cingulata, Dasypodidae) in Argentina}

\author{
Tatiana Sánchez ${ }^{1,2,3}$, Lucía Krapovickas ${ }^{1,3}$, M. Mónica Díaz ${ }^{1,3,4 *}$ and Rubén M. Barquez ${ }^{1,3}$ \\ 1 PIDBA (Programa de Investigaciones de Biodiversidad Argentina), Facultad de Ciencias Naturales e Instituto Miguel Lillo, Universidad \\ Nacional de Tucumán, Miguel Lillo 205, San Miguel de Tucumán, 4000 Tucumán, Argentina \\ 2 CRILAR (Centro Regional de Investigaciones Científicas y Transferencia Tecnológica) Entre Ríos y Mendoza s/n, 5301 Anillaco, La Rioja, \\ Argentina \\ 3 CONICET (Consejo Nacional de Investigaciones Científicas y Técnicas), Argentina \\ 4 Fundación Miguel Lillo; Miguel Lillo 255, San Miguel de Tucumán, 4000 Tucumán, Argentina \\ * Corresponding author. E-mail: mmdiaz@lillo.org.ar
}

\begin{abstract}
The early distribution of Euphractus sexcinctus in central-southwestern Argentina is here confirmed through an historical record from La Rioja province that was found at the Buenos Aires "Museo Argentino de Ciencias Naturales Bernardino Rivadavia", and neglected since 1935. The specimen corresponds to a complete head, with skull included, preserved in alcohol, collected by Dr. Salvador Mazza.
\end{abstract}

Key words: La Rioja, Argentina, systematic collections, historical distibution, Six-banded Armadillo

The general knowledge about the distribution of mammals of Argentina was originally restricted to information obtained rather randomly, and just in the last 40 to 50 years have systematic surveys been started by mammalogists specialized in diverse groups (Barquez et al. 2006; Pardiñas 2006). However, few professionals have studied national and international systematic collections, and for that reason it is quite common to find records that document the presence of a species in a region where they may no longer exist due to the rapid agricultural changes and urbanization. This is the case a new species of marsupial described from the Jujuy province, Argentina (Díaz et al. 2002) based on a specimen deposited at the American Museum of Natural History of New York that was collected in 1962. Recently, while reviewing the mammal collection of the "Museo Argentino de Ciencias Naturales Bernardino Rivadavia" (MACN), we have been able to find a specimen of $E u^{-}$ phractus sexcinctus (Linnaeus 1758)(Figure 1), consisting of a complete head with skull included, from La Rioja, a province where the species had not been documented with voucher specimens until now. The specimen was compared with a specimen deposited at the CML (Colección Mamíferos Lillo, University of Tucumán and Fundación Miguel Lillo, Argentina) to corroborate its identity, in addition to its large size, the diagnostic character of the species, a single "nuchal" band between the head and the scapular plate, is clearly evident (Figure 1). This finding extends the previously known distributional area of this species to southwestern Argentina in La Rioja province, suggesting that ancient stories about its distribution (Roig 1989, 1991) have real support.

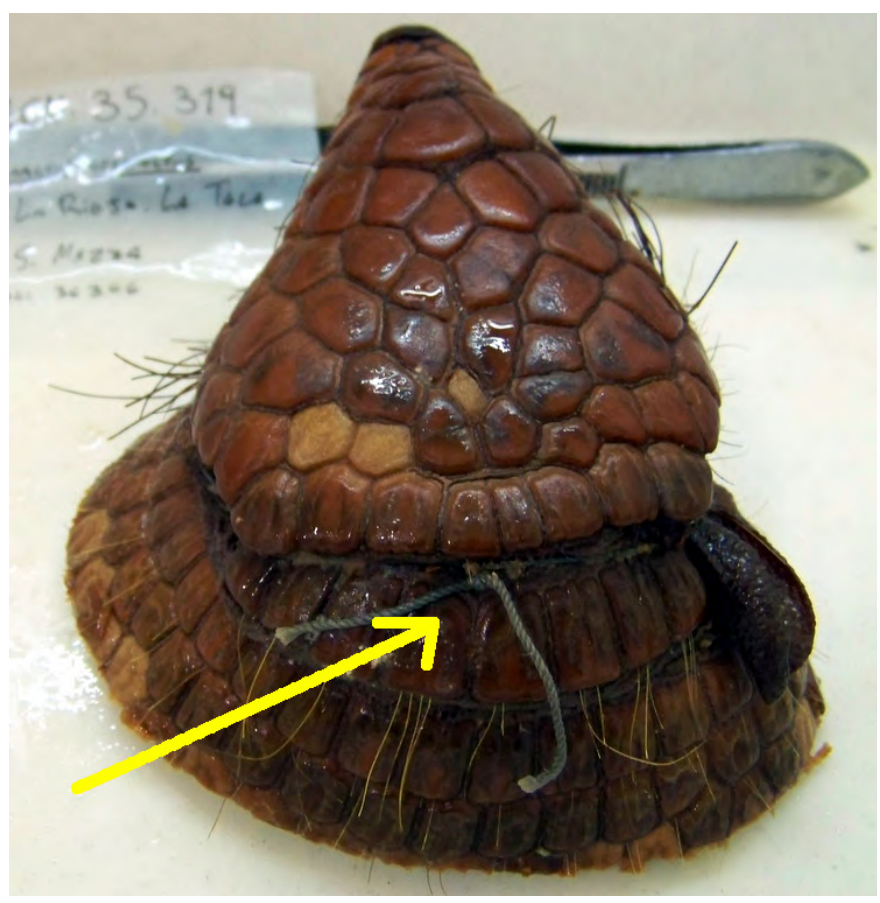

Figure 1. Specimen of E. sexcinctus (MACN 35.319) deposited at the "Museo Argentino de Ciencias Naturales Bernardino Rivadavia", from La Rioja province, Argentina. The yellow arrow points the single nuchal band, between the head and the scapular plate, which diagnoses this genus. 
Agüero et al. (2005) cited five species of xenarthrans from La Rioja [Chaetophractus vellerosus (Gray 1865), Chaetophractus villosus (Desmarest 1804), Chlamyphorus truncatus Harlan 1825, Tolypeutes matacus (Desmarest 1804), and Cabassous chacoensis Wetzel 1980], but only the presence of the first three were accepted by Vizcaíno et al. (2006). Later, Monguillot and Miatello (2009) added another species [Zaedyus pichiy (Desmarest 1804)] to the province, from Parque Nacional Talampaya. More recently, an analysis developed by Abba et al. (2012) updated the list of species from Argentina, elevating to seven the number of species from La Rioja, and including Tamandua tetradactyla (Linnaeus 1758), a representative of Vermilingua, which was already documented in Agüero et al. (2003), although was not published in a scientific journal.

The record herein reported represents documented information about a site of historical distribution for Euphractus sexcinctus, bringing to eight the number of xenarthrans with voucher specimens for La Rioja province. The specimen was collected by Dr. Salvador Mazza (collecting number 36366) in La Tala (Capital Department, La Rioja province) ( $29^{\circ} 36^{\prime} \mathrm{oo}^{\prime \prime} \mathrm{S}$, $066^{\circ} 52^{\prime} \mathrm{o}^{\prime \prime} \mathrm{W}$, Figure 2), and deposited at the museum of Buenos Aires "Museo Argentino de Ciencias Naturales Bernardino Rivadavia" (MACN 35.319) as complete head with skull included, preserved in alcohol (Figure 1). The collecting locality is $20 \mathrm{~km}$ south of the capital city of La Rioja and corresponds to the Dry Chaco Ecoregion, near the border with Monte Desert Ecoregion.

Although the presence of this species in La Rioja is here documented for the first time with a voucher specimen from 1935, it is necessary to mention that there are no other records from the province. This record is historically interesting because it supports ideas by Roig (1989, 1991), who mentioned that in the past this species was known in Catamarca and Tucuman provinces, in reference to data provided by Wetzel (1985). Also, in both publications, Roig highlights the presence of this species in the late 19th century, in the surroundings of the lake region (the lakes disappeared in the early part of the last century) of northeastern Mendoza, and in this sense our record fills a distributional gap between the provinces of Catamarca and Mendoza (Figure 2).

Abba et al. (2012), based on museum specimens, validate the presence of Euphractus sexcinctus in the province of Tucuman, but pointed out the lack of confirmed information for the provinces of Catamarca and La Rioja. It is also interesting that Abba et al. (2012: p. 130) emphasize that "An interesting result of the predictive model is that in central Argentina, around the Sierras Grandes of Cordoba, appears a core of intermediate probability of occurrence, which coincides with a recent finding of a plaque at an archaeological site suggesting that the species may have occurred there in the

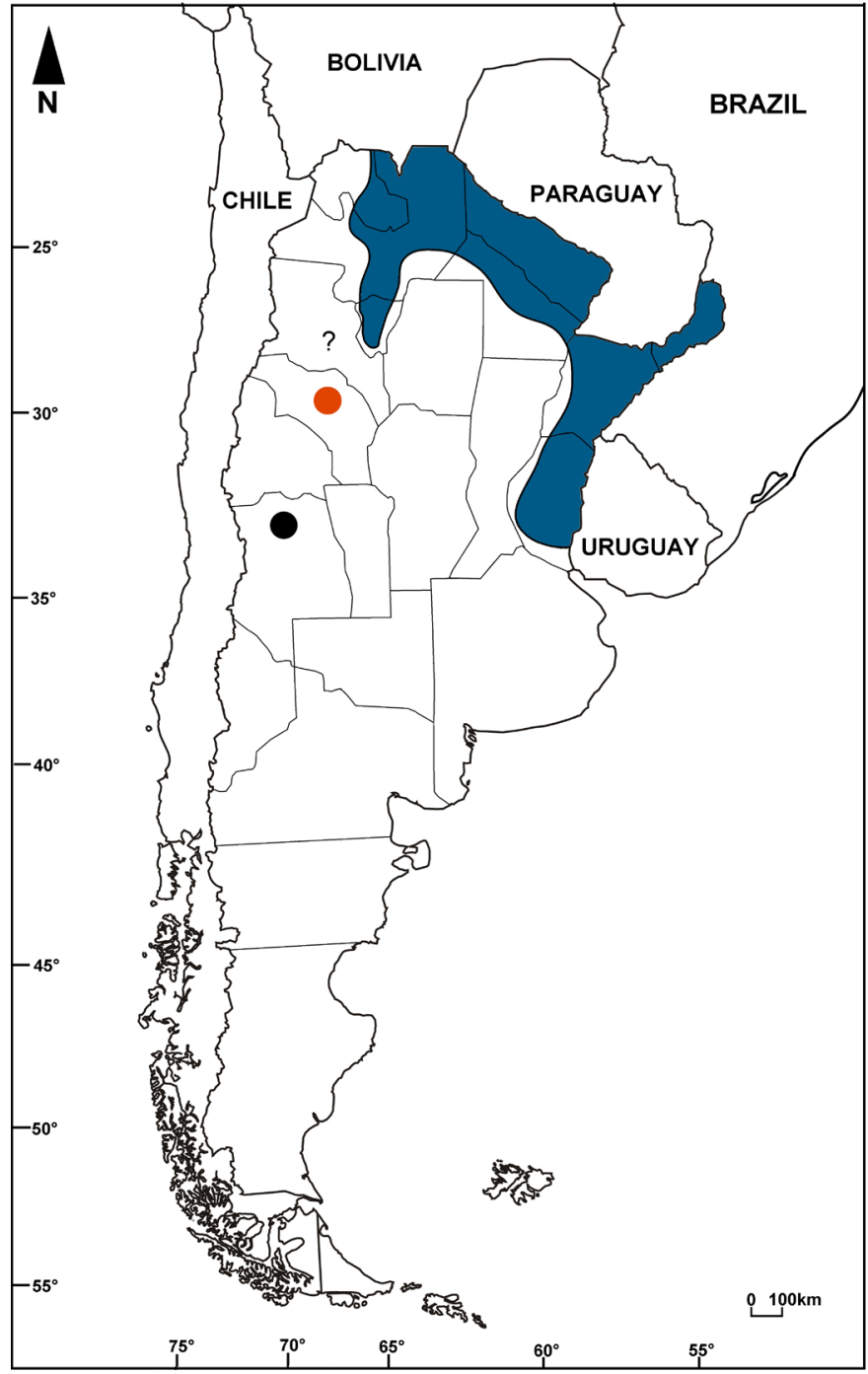

Figure 2. Map showing the current distribution of $E$. sexcinctus (in blue) and the new record of La Rioja (orange); the black dot indicates the approximate area of the historical record of Mendoza province, and the question mark indicates the likely historical records in Catamarca province as indicated by Wetzel (1982).

past". Additionally, Abba and Vizcaino (2011) and Abba et al. (2012) have questioned whether Buenos Aires is the city of origin of a specimen (MCZ 19502) deposited in the Museum of Comparative Zoology of Harvard, identified as Euphractus sexcinctus. Probably the reasons for their doubts were based on the fact that Buenos Aires is quite far from any of the known localities for the distribution of this species, but we have found that the referred specimen was, in effect, misidentified in the MCZ catalogues, and is actually Chaetophractus villosus.

There is a need for developing further detailed studies on the historical distributions of Argentina's mammals, including the analysis of specimens deposited in collections, both national and international; if studies on systematic collections were made more often, the protection of the species would be favored and we might be able to guard against possible impacts of environmental deterioration for numerous species of wildlife. 


\section{LITERATURE CITED}

Abba, A.M., M.F. Tognelli, V.P. Seitz, J.B. Bender and S.F. Vizcaíno. 2012. Distribution of extant xenarthrans (Mammalia: Xenarthra) in Argentina using species distribution models. Mammalia 76: 123-136. doi: 10.1515/mammalia-2011-0089

Abba, A.M. and S.F. Vizcaíno. 2011. Distribución de los armadillos (Xenarthra, Dasypodidae) en la provincia de Buenos Aires, Argentina. Mastozoología Neotropical 18: 185-206. http:// www.sarem.org.ar/wp-content/uploads/2012/11/SAREM_ MastNeotrop_18-2_02_Abba.pdf

Agüero, J.A., J.D. Díaz and D. González. 2003. Presencia y características del hábitat asociadas a Tamandua tetradactyla en las Sierras de los Llanos de La Rioja; pp. 81, in: Resúmenes XVIII Jornadas Argentinas de Mastozoología. La Rioja, Argentina: SAREM (Sociedad Argentina para el Estudio de los Mamíferos).

Agüero, J.A., T.G. Rogel, A.R. Bamba, P.C. Páez, C.E. Pellegrini and E.M. Virlanga. 2005. Diversidad y distribución de Dasipódidos en el Chaco árido de la provincia de La Rioja; pp. 98, in: Resúmenes XX Jornadas Argentinas de Mastozoología. La Rioja, Argentina: SAREM (Sociedad Argentina para el Estudio de los Mamíferos).

Barquez, R.M., M.M. Díaz and R.A. Ojeda. 2006. Mamíferos de Argentina, sistemática y distribución. SAREM (Sociedad Argentina para el Estudio de los Mamíferos). 359 pp.

Díaz, M.M., D.A. Flores and R.M. Barquez. 2002. A new species of gracile mouse opossums, genus Gracilinanus (Didelphimorphia: Didelphidae), from Jujuy province, Argentina. Journal of Mammalogy 83: 824-833. doi: 10.1644/1545-1542(2002)083<0824:ANSOGM>2.0.CO;2

Monguillot, J.C. and R. Miatello. 2009. Presencia de Cabassous chacoensis en el Parque Nacional Talampaya, La Rioja, Argentina. Edentata 8-10: 56-57.

Pardiñas, U.F.J. 2006. La encrucijada de los mamíferos vivientes y los estudios taxonómicos en la Argentina. Mastozoología Neotropical 13: 5-9. http://www.sarem.org.ar/wp-content/
uploads/2012/11/SAREM_MastNeotrop_13-1_01_Editorial.pdf

Roig, V.G. 1989. Desertificación y distribución geográfica de mamíferos en la república argentina; pp. 263-286, in: F.A. Roig (ed.). Detección y control de la desertificación, conferencias, trabajos y resultados del curso latinoamericano Mendoza, Argentina, 1-25 de octubre de 1987. CRICYT, CONICET.

Roig, V.G. 1991. Desertification and distribution of mammals in the southern cone of South America; pp. 239-279, in: M.A. Mares and D.J. Schmidly (eds.). Latin American mammals: their conservation, ecology, and evolution. Norman, Oklahoma: University of Oklahoma.

Vizcaíno, S.F., A.M. Abba and C.M. García Esponda. 2006. Megaorden Xenarthra Cope, 1889; pp. 46-56, in: R.M. Barquez, M.M. Díaz and R.A. Ojeda (eds.). Mamíferos de Argentina, sistemática y distribución. SAREM (Sociedad Argentina para el Estudio de los Mamíferos), Argentina.

Wetzel, R. M. 1982. Systematics, distribution, ecology, and conservation of South American edentates; pp. 345-376, in: M. A. Mares and H. Genoways (eds.). Mammalian biology in South America. Special Publication Series, Pymatuning Laboratory of Ecology, University of Pittsburgh, Pennsylvania.

Wetzel, R.M. 1985. Taxonomy and distribution of armadillos, Dasypodidae; pp. 23-46, in: G.G. Montgomery (ed.). The evolution and ecology of armadillos, sloths and vermilinguas. Washington, D.C.: Smithsonian Institution Press.

Authors' contribution statement: TS reviewed the museum specimen. RMB researched the historical data. LK translated the text to English. TS, LK, MMD, RMB wrote the text. MMD drew the map.

Received: May 2014

Accepted: February 2015

Editorial responsibility: Maria Luisa Jorge 